\title{
Sabtu satu atap: collaboration and social education program for elementary school students and special students of laniang in makassar city
}

\author{
Sitti Khadijah Kitta \\ Department of Psychology \\ Faculty of Medicine \\ Hasanuddin University \\ Makassar, Indonesia \\ tijakitta@gmail.com
}

\author{
Andi Aisyah Alqumairah \\ Department of Psychology \\ Faculty of Medicine \\ Hasanuddin University \\ Makassar, Indonesia \\ andiaisyah17@gmail.com
}

\author{
Achmad Mukhlisin \\ Department of Mathematics \\ Faculty of Mathematics and \\ Natural Science \\ Hasanuddin University \\ Makassar, Indonesia \\ achmad.h12114029@gmail.com \\ Dinda Tri Lestari \\ Department of Nutrition \\ Faculty of Public Health \\ Hasanuddin University \\ Makassar, Indonesia \\ dindatrilestari97@gmail.com
}

\begin{abstract}
Lack of space to interact is one of the causes of normal children not collaborating with disable child which refer to discrimination. This needs to be minimized early in children who are in the mid stage of development. Regular elementary school students and special students of Laniang are studying in the same school environment. However there is less visible social interaction. The implementation of Sabtu Satu Atap program aims to provide social education for the students to interact and collaborate each other. This program is divided into Tiru Kata Kita, Attachment, Siswa Kami Peduli Lingkungan (Siskamling), Berbagai Main, and Experiential Learning. Measurement of program effectiveness is done using interview method, observation, and pretest-posttest. Interviews with teachers and principals indicate that program has creative activities in enhancing student interaction and collaboration. Observations made also indicate a change in the behavior of regular elementary school students and special students of Laniang in interacting. The result of pretest-posttest data obtained was analyzed using t-paired test analysis with SPSS for Windows version 23 that $t$ value is 10,695 with significance value $<0,05$. This concludes that Sabtu Satu Atap Program is effective in improving collaboration and social interaction between elementary school and extraordinary students of Laniangin Makassar city.
\end{abstract}

Keywords: Disability, Social Education, Collaboration.

\section{INTRODUCTION}

Discriminative acts that occur in the community environment is a form of rejection of individual differences. Discrimination takes place at the level of the majority community suppressing the minority community with the result of the powerlessness of the community. Discrimination often occurs for persons with disabilities due to physical and mental limitations. Therefore, the need for, awareness-raising of equality between persons with disabilities and normal people from an early age is included in the mid-childhood. The stage of social development for the childhood of the child begins to identify changes in relationships with peer [1]. Children at this stage begin to build friendly relations, although the meaning of the friends they understand is not the same as the meaning of friendship in adults. At this stage, people with disabilities also experience the same period but differ in acceptance.

Lack of space to interact is one of the causes of normal children can not understand the children with disabilities. This lack of interaction process led to discrimination towards special children, even in onestop schools such as the Laniang Foundation. At the foundation, specialize schools and regular schools are united under the same roof. There is no barrier that limits these two schools, but there is no blending that should have been done. Children tend to think the special children are not their playmates. In fact, not infrequently children restrict relationships or relationships with people with disabilities in the social environment. Children just need to be made aware of 
the existence of equality. The acts of discrimination need to be minimized by way of teaching to children from an early age. Therefore, the Sabtu Satu Atap program was born as a medium of intermingling between normal and disabled children.

This program is considered appropriate to be done as a socialization to children who are in the middle stage of child development. They need to be accompanied to understand how the friendship relationships should be. Children need to be guided to realize equality and to avoid doing any acts of discrimination. When children and children with disabilities are taught to socialize, they will eventually be able to forge relationships. The relationship that exists between the two will teach the child how to appreciate each other and be grateful. Fertilization of awareness about equality between persons with disabilities should be done from an early age. Continuous teaching will provide insights to children that people with disabilities should be respected. This reduces discrimination at the intercourse stage of the child.

\section{LITERATURE REVIEW}

\section{A. Children Development}

Children entering the age of 6 to 11 years or entering their mid-term developments have several developmental tasks to follow as children begin to focus on shaping friendships, developing mental abilities (understanding and monitoring their thinking and others), skills in learning, self-evaluation, and group play [2]. These developmental tasks are supported by an increasingly complex capacity of children in social, emotional, and cognitive activities.

On the social aspect, children enter the industry stage vs. low self-esteem [3]. School-age children begin to learn to work and play on activities directed to gain the ability to work and learn the rules of working together. In the development of social aspect, children who are in elementary school and special education need to finish their development task in learning to cooperate. The role of a social relation or friendship in a child can help the child learn to understand the thinking of others from different perspectives, to increase sensitivity to rules and pressures in groups, and to bring social relations closer [2]. Social relations or friendship in children gives 3 forms of contribution in the development of social aspects [2]. The first contribution is that children can increase their appreciation for the opinions given in their play groups. The second contribution is that children can improve knowledge of the rules in the group. Then the last contribution, the children can learn to understand the emotional value of a friendship relation.

Interactions among peers can improve a child's moral understanding. When children negotiate and compromise with their peers, the child realizes that social life can be based on equal relations rather than authority [4]. Peer discussions and role play on moral issues have provided the basis for interventions aimed at improving the moral understanding of children. Meanwhile, in the aspect of moral development, children develop three moral components: moral identity, moral character, and moral examples [1]. Therefore, there needs to be assistance and direction from adults related to good and bad things that exist in the community.

Cognitively, children ages 7 to 11 enter a developmental stage of concrete operations characterized by logical reasoning about concrete events and classify objects [1]. The development of motor aspects also increased in middle-aged children due to increased myelination of the central nervous system so that the motor skills of the course and finer the better. All developments in the social, cognitive, moral, motor aspects of the child need to be continuously stimulated in order to improve the child's ability. Therefore, children need to be given stimulation through games or activities that can develop aspects of its development. The series of activities on "Sabtu Satu Atap" Program is conducted based on the child development aspect theory.

\section{B. Person with Disability}

People with disabilities are anyone with long-term physical, intellectual, mental, and/or sensory limitations who interact with the environment may experience barriers and difficulties to participate fully and effectively with other citizens based on equal rights (Law no. 8 the Year 2016). People with physical disabilities are persons with the impaired motor function such as amputations, paralyzed, cerebral palsy (CP) caused by stroke, leprosy, and small people. Autistic disorder (autistic disorder) is a disorder of the autism spectrum that causes deficiencies in social relations, abnormalities in communication, as well as behavior with restricted, repetitive, and stereotyped patterns. Similarly, Asperger syndrome (Asperger syndrome) that causes children to have disorders in nonverbal language [1]. Adjustment disorder is also a disturbance of human abnormalities that can be attributed to less harmonious friendships or other problems [5]. Some of the main characteristics of adjustment disorder are experiencing sadness, crying, feeling hopeless, worrying, anxiety, nervousness, Worrying.

Based on data provided by National Social and Economic Survey (susernas) 2012, the population of people with disabilities is 6.515 .500 of the 244.919.000 from the estimated population of Indonesia. Meanwhile, according to Social Protection and Service Program (PPLS) in 2012, numbers of person with disabilities nationally is 3.838 .985 [6].

The environment greatly affects the growth and development of people with disabilities in terms of mental and social. According to WHO (2011), there are some environmental attitudes towards people with disabilities that produce a negative impact on the 
individual. Attitudes include disability in-bully by peers, lack of community acceptance, and discrimination. Bullying is an aggressive and pressing behavior, either in the form of physical action directly or attacking through verbal [7]. Such attitudes and behaviors can have a negative impact on children and adults with disabilities leading to low self-esteem, social anxiety, and feeling alone. In addition, the negative impact of discrimination that refers to bullying behavior will cause children to become depressed, to feel inferior social status, and to avoid friends [2].

Negative actions tend to be done by adults to persons with disabilities. However, moral values are mostly taught from childhood. Individual morale gained enormous influence from the moral education process acquired in childhood. Thus should various mentoring and development is necessary for children from an early age. The most human development aspect develops during childhood, therfore adults need to provide a variety of stimuli especially for the moral aspect. One of the most prevalent acts is the act of discrimination. The things that individuals acquire in childhood will affect the individual to adulthood [8].

Preventing the development of discrimination from generation to generation can be done by providing assistance to children, especially at the stage of development of middle children. At this stage, the cognitive individuals begin to be able to accept explanations related to matters relating to their social environment. Not only have that, at this stage of development, the individual social aspects begun to develop. The stage of social development of middle children is that children begin to identify changes in relationships with peers [1]. Children at this stage begin to build friendly relations, although the meaning of the friends they understand is not the same as the meaning of friendship in adults.

Therefore, the provision of some collaboration and social education activities to elementary and junior high school students can be a place to get to know each other, interact, and enhance collaboration with each other. Activities provided can also assist students in terms of providing moral understanding to increase awareness of mutual collaboration and do not exhibit discriminatory attitudes. Activities that are given in addition to improving social interaction, can also stimulate aspects of child development to complete the development tasks of motor aspects of fine, rough motor, cognitive, language, moral, and social.

Therefore, the provision of some collaboration and social education activities to elementary and junior high school students can be a place to get to know each other, interact, and enhance collaboration with each other. Activities provided can also assist students in terms of providing moral understanding to increase awareness of mutual collaboration and do not exhibit discriminatory attitudes. Activities that are given in addition to improving social interaction, can also stimulate aspects of child development to complete the development tasks aspects such as fine and gross motor, cognitive, language, moral, and social.

The expected output of this program is that it can help children to establish relationships with each other so that normal children can receive children with disabilities. On the contrary, children with disabilities can adapt to the community environment in general. In addition, normal children and people with disabilities are also able to collaborate and respect each other. The program also assists children in carrying out their developmental stages in the presence of various stimulant.

A. Participants.

Participants in this program are student with disability and student elementary school.

B. Community service program that aims to collaborate students of SD and SLB Laniang city of Makassar is done with various activities. Socialization to parents conducted on Saturday, April 1, 2017, is the first step to provide an explanation of the program undertaken, the form of activities and implementation mechanisms to parents of students. Socialization to parents is also done to provide an understanding of the importance of building interaction, relationships, and positive perceptions between normal children and children with special needs, as well as respect for each other regardless of physical completeness, psychological state, and other shortcomings.

C. After the socialization to parents, various activities are given to students to achieve the goal of the program is to collaborate and educate students. Implementation stage is done in some activities that are Tiru Kata Kita, "Me, They, She Becomes Us" (attachment), play activity (social play, sensory motor play, symbolic play, practice play, and constructive play), our students care for environment Siskamling), and experiential learning activities. In addition to activities aimed at elementary and junior high school students, there are also parenting courses along with parents to illustrate good parenting styles.

Procedures

\section{Me, You, and He Becomes Us (Attachment)}

Attachment was an introduction and adjustment activity as a first step to get to know each other which was held on Saturday 15 April 2017. The activities were the game of snake ladder and ball sharing to bring students closer to each other. Each student was divided into several groups to pass the ball from by interacting with each other. Snake game ladder was a media for students to start to know his/her friends. The counselor also accompanied as a facilitator during the activity to 
help the special education students if they got barriers in terms of communicating.

\section{Siskamling (Our Students Care for the Environment)}

Siskamling was an activity that aims to improve collaboration and cooperation of students while learning, playing, and working together to care for the environment. This activity was held on Saturday 22 April 2017. Siskamling activity was divided into two parts: planting trees and decorating pots and making our trees. Each student was divided into 6 groups which are a collaboration of elementary and junior high school students. Each group collaborated on planting seeds and then decorated the pots with various papers, ribbons, and beads. Our tree making aimed to provide a place for students to write their dreams, dreams, hopes, and feelings to hang on the branches that have been provided. This program was conducted outside the classroom precisely around schools and school field.

3. Play Share (Social Play, Sensory Motor Play, Symbolic Play, Practice Play, and Constructive Play activities)

Sharing was an activity that facilitates students playing while studying with the aim of improving the attachment, closeness, and intimacy of regular elementary school students and special students of Laniang. Play sharing activities took place on Saturday 29 April 2017, The game given in this activity were games that prioritize collaboration, cooperation, and solidarity with each other. The games included group games such as solving problems with puzzles, creating patterns from origami, and grouping objects. In addition to creating collaboration among students, playing while learning can also stimulate aspects of child development, namely aspects of fine and gross motor development, cognitive, emotional, social, language, and moral. This activity also taught students to be able to share based on aspects of moral development, give toys owned by friends, shake hands, and know each other.

4. Experiential Learning

Experiential learning is an activity that aims to collaborate students of SD and SLB Laniang in expression and develop interests, talents, and potential owned, especially in the field of art. The event took place on Saturday, May 6, 2017, in several classes, namely dance classes, crafts, singing, and painting. The dance classes provide students with assistance to learn collaborative traditional dancing among elementary and junior high school students. Dance type that is taught is a dance from South Sulawesi and also dance creations. The craft class provides students with assistance to collaborate on assembling materials into beautiful works called collaborative work of elementary and SLB Laniang students. Some forms of handicrafts made are the place of tissue, the bottle of the pen, frames, wall hangings, open circuit, and so forth. The painting class provides students with assistance to mix and match the various colors to be a collaborative painting of students between elementary and junior high school. Singing Class is a class that provides mentoring to students to sing along with the National Republic of Indonesia songs and children's songs.

\section{Methods}

The data were collected by using 3 methods: observation of student behavior, interview with teacher and principal, and analyzing pre-test and posttest data to see the effectiveness of the program. Observation of student behavior was done by the recording method of checklist which contains the indicators of the behavior of social interaction of child. Meanwhile, interviews with principals and teachers were conducted before and after the program based on the interview guidelines. Data collection was also carried out with the dissemination of [9] measuring instruments that measure children's social interactions based on the theory of social aspects of Park and Burges.

Sabtu Satu Atap program could run independently in SD and SLB Laniang Kota Makassar with guidebook facilities that have been compiled and distributed, sustainable community development in community empowerment, a model of community empowerment methods and social education, development at higher school level, and provide changes in support of the education movement for disability in Indonesia. The sustainability of the program is also supported by participation and support from various parties such as parents, schools, PK-PLK supervisory agencies (Special Education-Education of Special Services), community cooperation, and community sustainability.

\section{Socialization of the Program}

\section{RESULT}

Socialization was attended by 33 parents of students, the school, volunteers of Satu Atap Community, as well as teachers of SD and SLB Laniang Makassar. This activity was also attended by the supervisor of PK-PLK (Special Education and Education of Special Services) of South Sulawesi Province. In this socialization activity, the presentation of the concept of Sabtu Satu Atap program, program objectives, activity items, implementation time, and expected outcomes was presented. In addition, there was also an explanation of the child's psychological benefits of the program by a clinical psychologist. In this activity, one of the parents of special education students expressed the hope for the sustainability of this program and the existence of communication containers among parents. 


\section{Imitate Our Word / "Tiru Kata Kita"}

Activity began with a sign language alphabet recognition. After that, Laniang elementary students were taught basic sign communication such as greeting, inviting play, asking news, asking for help, calling, and various other communication languages using sign language. Not only Laniang Elementary School students attended this activity, but special education teachers and parents also joined in listening to explanations and learning sign language. The activity of Tiru Kata Kita ended with the giving of games to the students of Laniang Elementary School. This activity was followed by 32 students of elementary school dan 8 special education students. It could also be seen from elementary students who were able to deliver short messages using sign language. Most who followed this activity, memorized the letters from $A$ to $Z$ using sign language. In the implementation of this activity, elementary students could get acquainted with special education students who were deaf using sign language. In addition, some parents asked for this re-training because their children start communicating easily with their parents.

\section{Attachment}

The activities were the snake ladder games and ball sharing to bring students of elementary school and special education of Laniang to each other. Students are divided into groups in a ball-sharing game. Each student passed the ball from one bucket to the other bucket by interacting with each other. Meanwhile, a ladder snake game conducted with the introduction of each group member first, then every student who was arrested during the game took place given the opportunity to name his friend. Activities followed by 29 students from elementary school dan 14 students from special education. Elementary school and special education students can get to know the names of their friends to each other because the task of memorizing names was a challenge in this game. Each group also helped each other and interact during the game. Not only that, elementary and junior high school students began to be able to collaborate even in a short duration of time.

\section{Siskamling (Our Students Care for the Environment)}

Siskamling activity was divided into two parts: planting trees and decorating pots. Each student was divided into 6 joint groups of elementary and junior high school students, each group was accompanied by a PKM-M team and a volunteer. Each group took a space that has been provided, then put the seeds of plants into pots, then water the plants. After planting the tree, the pot is decorated with origami paper, ribbons, and beads directed by the volunteers. The second part of the Siskamling activity was Our Tree. Each student is given a piece of fruit-shaped paper and a boat to write down ideas, wishes, and dreams. After that, all students put their wishes on the tree. This activity was attended by 32 elementary school students and 26 students of special education. Throughout this activity, the elementary students started to become more familiar with special education students. During the initial meetings, many elementary students protested to the facilitators when there were special education students in the group. However, at this meeting, the regular elementary students begin to call the facilitator and report if there are no special education students in the group. They also began to look after each other in decorating pots. If the facilitator forgot the names of some special education students, regular elementary students would help to remind. They were seen getting to know all the names of the friends who joined the program Satu Atap every Saturday.

\section{Sharing Play}

This activity consisted of 3 games that could enhance collaboration of regular elementary school students and special education of Laniang. This activity could stimulate aspects of good motor development, cognitive, and student social skills. Each student was divided into 4 major groups consisting of elementary and junior high school students. The first game, which was to form patterns from origami paper. Students made boats, boats, flowers, birds, houses, and various other patterns. Each student exchanged patterns made with his/her group's friends. The second game, which was a puzzle compiled together between elementary and special education students. The third game was grouping objects where each group collaborated to collect items according to their type such as toiletries, school equipment, etc. The activity was followed by 25 elementary school students and 16 students of special education. Elementary school and special education students were beginning to look at collating puzzles together, grouping objects, and folding paper. Special education students found difficulties in paper folding. However, when asked to share the work to a friend, students gave each other opportunities and shook hands.

\section{Experential Learning}

Each student was divided into 5 classes: dance class, singing class, painting class, and craft class. Each class was accompanied by a volunteer and a PKM-M team to train students to develop their interests and talents. Each group that had gone through one class will roll to the next class so that each student perceives all the classes. In terms of developing their talents, each group consists of elementary and junior high school students. This activity was attended by 15 elementary students and 10 students of special education. Elementary and special education students complete the artwork together, such as painting, making crafts, and performing the dance that has been studied. Regular elementary school and special education students exemplified each other while practicing dance moves, telling the colors of the paintings used, picking up handicraft materials, and singing.

The Sabtu Satu Atap program run effectively. This was demonstrated by interviews with the teachers 
and principals who stated that the program had creatively promoted social interaction. The school also said that there was a change in the behavior of elementary school students and special education of Laniang like elementary school students who started coming to visit in special education class corridor, greet the name of special education students, and special education students who could be invited to play with elementary school students. The results of observations conducted also indicate the existence of such behavior invites friends to play, greet, ask for help on the students of both elementary and special education of Laniang. In addition, the program wass also supported by the results of pre-test and post-test data processing that shows the effectiveness of the program.

Table 1.

Result of recap of pre-test and post-test data

\begin{tabular}{|l|l|l|}
\hline $\begin{array}{c}\text { Number } \\
\text { Subjek }\end{array}$ & $\begin{array}{c}\text { Pre- } \\
\text { test }\end{array}$ & $\begin{array}{c}\text { Post- } \\
\text { test }\end{array}$ \\
\hline $\mathbf{1}$ & 85 & 97 \\
\hline $\mathbf{2}$ & 101 & 105 \\
\hline $\mathbf{3}$ & 89 & 102 \\
\hline $\mathbf{4}$ & 84 & 101 \\
\hline $\mathbf{5}$ & 81 & 100 \\
\hline $\mathbf{6}$ & 85 & 104 \\
\hline $\mathbf{7}$ & 96 & 106 \\
\hline $\mathbf{8}$ & 84 & 105 \\
\hline $\mathbf{9}$ & 79 & 104 \\
\hline $\mathbf{1 0}$ & 83 & 101 \\
\hline $\mathbf{1 1}$ & 81 & 100 \\
\hline $\mathbf{1 2}$ & 87 & 102 \\
\hline $\mathbf{1 3}$ & 82 & 92 \\
\hline $\mathbf{1 4}$ & 84 & 97 \\
\hline $\mathbf{1 5}$ & 81 & 106 \\
\hline
\end{tabular}

Source : Data Processed at 2017

Data pre-test and post-test data were processed using SPSS 23 for Windows to prove that the Sabtu Satu Atap program is effective in improving the social interaction of elementary school students and special education students in elementary level of Laniang. Results of data processing as follows:
Table 2.

Results Data Processing

\begin{tabular}{|l|c|l|l|l|l|}
\hline & \multicolumn{3}{|c|}{ Paired Differences } & & \\
\hline & & $\begin{array}{l}\text { Std. } \\
\text { Devia } \\
\text { tion }\end{array}$ & $\begin{array}{l}\text { Std. } \\
\text { Error } \\
\text { Mean }\end{array}$ & t & Sig \\
\hline $\begin{array}{l}\text { Post- } \\
\text { Pre test }\end{array}$ & 16,00 & 5,794 & 1,496 & $\begin{array}{l}10, \\
695\end{array}$ & $\begin{array}{l}0,00 \\
0\end{array}$ \\
\hline
\end{tabular}

When viewed on $\mathrm{t}$-table with the level of $\alpha=5 \%$ and $\mathrm{df}=14$ obtained a value of 2.14479 . These results indicated that the value of $t$ arithmetic of 10.695> $t$ table was 2.14479. In addition, the significance value was smaller than 0.05 which is 0.000 . Therefore it could be concluded that the average value of pre- and post-treatment samples had a difference or not equal significantly. This suggests that the Sabtu Satu Atap Program was effective in enhancing the social interaction between students of special education and regular elementary school through a series of activities implemented.

\section{DISCUSSION}

This is also supported by the results of the study [10] which shows that children with physical disorders can build collaboration and social adaptation in the presence of good or warm communication from people in the social environment, especially their school friends. Schools need to direct non-disabled students to respect each other and make no distinction between friends, so that students with disabilities can adapt to the norms [11]. Writes that good adaptation is a condition when one is free from feelings of frustration or stress. This proves that if a good friend provides support for disability students to meet one aspect of adjustment, so students will feel cared for and not isolated from their environment [12].

In addition, the results of [13] research on deaf students at SMAN 10 and SMKN 8 Surabaya explained that there is a significant relationship between peer social support on the ability of students to adjust for disability in inclusive schools. Social support can be showed through the acceptance of diversity, communication, and social skills [14]. Support from non-disabled students and disability can be an intervention by mutually motivating to learn and interact [14].

Before Sabtu Satu Atap program is implemented, elementary and special education students rarely play, interact, or recognize each other's names. Elementary students are not seen coming to visit special education classes or interacting with them. Meanwhile, special education students are seen playing alone and do not geta long with the elementary students. But after the Sabtu Satu Atap program is implemented, many elementary and junior high school students who have known each other's names, invite to play or help. Elementary students are seen often visiting special education classes, greeting, or sitting together in the 
classroom corridors. This is also supported by the explanation of principals, teachers, and parents of students who participated in watching the activities take place. The effectiveness of the Sabtu Satu Atap Program can be a benchmark in enhancing benefits in various fields. This program can increase social interaction between people with disabilities and nondisabilities to work together to build their own potentials. Economically, collaborative programs that produce collaborative work of students can encourage the improvement of collaborative products such as crafts, displays, paintings, and so forth. Meanwhile, this program is also able to improve the art of children in creating various tasks.

\section{CONCLUSION}

Sabtu Satu Atap Program has been done every Saturday at SD and SLB Laniang Kota Makassar. The program that begins with the socialization to the parents of students, consists of several forms of activities items that are Tiru Kata Kita, Attachment, Siskamling (Students We Care Environment), Share Main, and Experiential Learning. The given activity items can stimulate the psychological aspects of student development. The results achieved and the effectiveness of the program is derived from the observation of changes in student behavior, interviews with principals and teachers, as well as pre and post tests indicating the program has been effective. The sustainability of the program is independently done by meeting with the school and the sharing of manuals as a guide for the school.

\section{REFERENCES}

[1] JW. Santrock. Life-Span Development Perkembangan Masa-Hidup. Edisi 13 Jilid 1 Jakarta PenerbitErlangga, 2012.

[2] BM. Newman, \& PR. Newman. Life-Span Development: A Psychosocial Approach. Canada: Wadsworth, Cengage Learning, 2012.

[3] J. Feist. \& G. Feist. TeoriKepribadian (EdisiKetujuh). Diterjemahkan oleh Handriatno. Jakarta: Penerbit Salemba Humanika, 2010.

[4] LE. Berk. Development the Lifespan: Dari Prenatal SampaiRemaja (TransisiMenjelangDewasa) (EdisiKelima). Diterjemahkan oleh Daryatno. Yogyakarta: Pustaka Pelajar, 2012.

[5] JS. Nevid, SA. Rathus, \& B. Greene. Psikologi Abnormal. Jakarta: Penerbit Erlangga, 2005.

[6] Badan Pusat Statistik. Survei Sosial Ekonomi Nasional (Susenas) Tahun 2012. Jakarta: Badan Pusat Statistik, 2012.

[7] M. Simbolon. "Perilaku Bullying pada Mahasiswa Berasrama”. (Universitas Indonesia Advent, Bandung). Volume 39, 233, 234, 2012.
[8] GC. Davison, JM. Neale, \& AM. Kring. Psikologi Abnormal. Edisi 9. Jakarta: Rajawali Pers, 2010.

[9] S. Slamet. Dinamika Kelompok. Jakarta: PT. Bumi Aksara, 2004.

[10] A. Muhtaz, Amiroh. "Proses Adaptasi Sosial Siswa Disabilitas dengan Siswa Nondisabilitas di Sekolah Inklusi (Studi Kasus pada SiswaTunanetra di SMP Inklusi Taman Pendidikan dan Asuhan Kabupaten Jember)". [undergraduate thesis]. University of Jember: Indonesia, 2015.

[11] AA. Schneiders. Personal adjustment and mental health. New York: Holt Rineheart\& Winston, 1964.

[12] C. Musselman, A. Mootilal, \& S. MacKay, S. "The social adjustment of deaf adolescents in segregated, partially integrated, and mainstreamed settings". Journal of Deaf Studies and Deaf Education 1, 52-63, 1996.

[13] SA. Hasan \& MM. Handayani. "Hubungan antara Dukungan Sosial Teman Sebaya dengan Penyesuaian Diri Siswa Tunarungu di Sekolah Inklusi”. Jurnal Psikologi Pendidikan dan Perkembangan, 3(2), 2014.

[14] R. Bond, \& E. Castagnera. "Peer support and inclusive education: an underutilized resource". Theory into Practice. 45 (3), 224229, 2006. 